\title{
Influence of $\mathrm{ABCB} 1$ gene polymorphisms on the pharmacokinetics of \\ verapamil among healthy Chinese Han ethnic subjects
}

\author{
Li-Mei Zhao, ${ }^{1}$ Xiao-Jing He, ${ }^{1}$ Feng Qiu, ${ }^{1}$ Ya-Xin Sun ${ }^{1} \&$ Jesse Li-Ling ${ }^{2,3}$ \\ ${ }^{1}$ Department of Pharmacy, Shengjing Hospital of China Medical University, ${ }^{2}$ Department of Medical \\ Genetics, China Medical University and ${ }^{3}$ Sino-Dutch Biomedical and Information Engineering School, \\ Northeastern University, Shenyang, China
}

\section{WHAT IS ALREADY KNOWN ABOUT THIS SUBJECT}

- The pharmacokinetics of verapamil have been assessed in a number of studies. - As a substrate of P-glycoprotein (P-gp), verapamil shows a large inter-individual variability in terms of plasma concentrations.

- It has been confirmed that polymorphisms of the $A B C B 1$ gene at positions 2677 and 3435 are related to the expression and function of P-gp.

\section{WHAT THIS STUDY ADDS}

- This study has confirmed that polymorphisms of $A B C B 1$ gene may influence the pharmacokinetics of verapamil among healthy Chinese Han ethnic subjects.

\section{Correspondence}

Professor Li-Mei Zhao, Department of Pharmacy, Shengjing Hospital of China Medical University, 36 Sanhao Street, Shenyang 110004 , China

Tel: +86 2483956565

Fax: +86 2423925108

E-mail:zhaolm@sj-hospital.org;

hxj730119@yahoo.com.cn

\section{Keywords}

ABCB1, pharmacokinetics, SNP, verapamil

\section{Received}

15 October 2008

Accepted

13 May 2009

\section{AIMS}

To assess the association between polymorphisms of the $A B C B 1$ gene and the pharmacokinetics of verapamil among healthy Chinese Han ethnic subjects.

\section{METHODS}

Based on polymorphisms of the $A B C B 1$ gene at positions 2677 and 3435, 24 healthy male participants were divided into three groups: 2677GG/3435CC $(n=6), 2677 \mathrm{GT} / 3435 \mathrm{CT}(n=12)$ and 2677TT/3435TT ( $n$ $=6$ ). Each subject had received a single oral dose of verapamil (80 mg) under fasting conditions. Multiple blood samples were collected over $24 \mathrm{~h}$, and plasma concentrations of verapamil were determined by HPLC. Pharmacokinetic characteristics were compared between the different genotypic groups.

\section{RESULTS}

The pharmacokinetics parameters of verapamil differed significantly among the three genotypic groups. AUC(last) was significantly lower among individuals with the $2677 \mathrm{TT} / 3435 \mathrm{TT}\left(159.5 \pm 79.0 \mathrm{ng} \mathrm{ml}^{-1} \mathrm{~h}\right)$ and $2677 \mathrm{GT} / 3435 \mathrm{CT}\left(189.3 \pm 73.1 \mathrm{ng} \mathrm{ml}^{-1} \mathrm{~h}\right)$ genotypes than those with the $2677 \mathrm{GG} / 3435 \mathrm{CC}$ genotype $\left(303.1 \pm 83.7 \mathrm{ng} \mathrm{ml}^{-1} \mathrm{~h}\right)(P=0.004$ and $P=0.008$, respectively). However, the $C L / F$ value was higher among subjects with the $2677 \mathrm{TT} / 3435 \mathrm{TT}\left(523.0 \pm 173.7 \mathrm{I} \mathrm{h}^{-1}\right)$ genotype than those with the $2677 \mathrm{GT} / 3435 \mathrm{CT}\left(452.2 \pm 188.6 \mathrm{I} \mathrm{h}^{-1}\right)$ or $2677 \mathrm{GG} / 3435 \mathrm{CC}$ $\left(265.4 \pm 72.8 \mathrm{I} \mathrm{h}^{-1}\right)$ genotypes. A significant difference was also found between the latter two groups $(P=0.034)$. In addition, the $C_{\max }$ tended to be higher among subjects with the $2677 \mathrm{GG} / 3435 \mathrm{CC}$ genotype than those with the $2677 \mathrm{GT} / 3435 \mathrm{CT}$ or $2677 \mathrm{TT} / 3435 \mathrm{TT}$ genotypes (42.2 \pm 3.9 vs $32.2 \pm 16.2$ vs $38.1 \pm 13.7 \mathrm{ng} \mathrm{ml}^{-1}$ ).

\section{CONCLUSIONS}

Our study showed for the first time that verapamil pharmacokinetics may be influenced by particular genetic polymorphisms of the $A B C B 1$ gene among healthy Chinese Han ethnic subjects. An individualized dosage regimen design incorporating such information may improve the efficacy of the drug whilst reducing adverse reactions. 


\section{Introduction}

Verapamil is one of the most widely used calcium ion influx inhibitors with anti-arrhythmic, anti-anginal, and antihypertensive properties, and is approved for the treatment of angina (including vasospastic and unstable types), atrial arrhythmias, and hypertension. Clinical use of the drug, however, has been complicated by a narrow therapeutic range and highly variable pharmacokinetics in individual patients [1,2]. Various factors including age, gender and drug interactions may influence the efficacy of verapamil [3-6], among which genetic factors are thought to contribute substantially to inter-individual variations in the disposition of the drug. Identification of genetic parameters predictive of optimal dosage is therefore of great clinical interest.

Verapamil is a substrate for P-glycoprotein (P-gp, a multi-drug resistance transporter), product of the $A B C B 1$ (ATP-binding cassette 1) gene. P-gp is widely expressed in tumour cells, but is also found on the apical surface of intestinal epithelial cells, the biliary canalicular membrane of hepatocytes, the luminal surface of the capillary cells forming the blood brain barrier, the brush border membranes of proximal tubules in the kidneys, and the adrenal cortex and placenta. As a transporter, it plays a significant role in drug disposition, i.e. absorption, distribution, and excretion, and may also be involved in secretion of steroids [7-9]. Although comparison of the uptake of two P-gp substrates, verapamil and vinblastine, showed that the intestinal absorption profile of verapamil was not affected by P-gp [10], several groups have concluded that the effect of P-gp on intestinal absorption of the drug may not be predicted based on in vitro data [11, 12].

The $A B C B 1$ gene has been found to be highly polymorphic between individuals and different ethnic groups. Three most frequently occurring single nucleotide polymorphisms (SNPs) of the gene included 1236T in exon 12, 2677T/A in exon 21 and 3435T in exon 26 [13]. In recent years, clinical studies have been conducted worldwide to investigate the association between polymorphisms of the $A B C B 1$ gene, expression and function of P-gp and pharmacokinetics of its substrates. Discrepancies, however, seem to exist between the results [14-23]. As genotypes comprising particular SNPs may be responsible for the alteration in the functions of P-gp $[16,24,25]$, two SNPs of the $A B C B 1$ gene, i.e. 2677T/A and 3435T, are currently considered as the main genetic factors implicated. In this study, we attempted to assess the influence of such SNPs on the pharmacokinetics of verapamil among Chinese Han ethnic subjects.

As verapamil is also known to be a substrate of CYP3A4, oral clearance of the drug, therefore, may be influenced by not only its absorption and/or transportation via P-gp, but also metabolic pathways. Considering the relatively low prevalence of the mutant alleles in the Chinese populations and uncertain in vivo function(s) $[26,27]$, we did not assess the effect of CYP3A4 polymorphisms in present study. On the other hand, CYP3A5 genotypes have recently been associated with oral clearance and verapamil response in healthy subjects as well as patients $[28,29]$. The CYP $3 A 5 * 3$ allele is characterized by an A $\rightarrow$ G SNP in intron 3 of the gene, which has created a cryptic consensus splice site and exon 3B. The mRNA of this splice variant contains a premature stop codon that can result in almost complete absence of CYP3A5 protein [30]. As a common mutant, the allelic frequency of $\mathrm{CYP} \mathrm{A} 5^{*} 3$ reached $93 \%$ in Caucasians, $72 \%$ in Asians, and $32 \%$ in African Americans. To exclude the effect of the CYP $3 A 5^{*} 3$ allele on our result, we also detected the CYP3A5*3 allele in our samples.

\section{Methods}

\section{Subjects}

Among 202 subjects who had been previously genotyped for $A B C B 1$ exons including polymorphisms $2677 \mathrm{~T} / \mathrm{A}$ and $3435 T, 24$ healthy males (Han ethnics) were enrolled. These included six individuals with $2677 \mathrm{GG} / 3435 \mathrm{CC}$ (age $22.3 \pm$ 0.8 years, BMI $\left.21.54 \pm 1.99 \mathrm{~kg} \mathrm{~m}^{-2}\right)$, six with $2677 \mathrm{TT} / 3435 \mathrm{TT}$ (age $22.2 \pm 1.0$ years, BMI $21.22 \pm 1.47 \mathrm{~kg} \mathrm{~m}^{-2}$ ) and 12 with $2677 \mathrm{GT} / 3435 \mathrm{CT}$ (age $21.9 \pm 1.1$ years, BMI $21.24 \pm$ $1.71 \mathrm{~kg} \mathrm{~m}^{-2}$ ) genotypes, and no significant difference was detected between different genotypic groups. The study protocol was approved by the ethics committee of Shengjing Hospital affiliated to China Medical University and performed according to the rules of the Helsinki declaration. Participants were given both oral and written information about the study protocol before a written consent was obtained.

All subjects were non-smokers and in good health as determined by medical history, physical examination, ECG evaluation and routine laboratory tests (blood chemistry, haematology and urine analysis). They were asked not to take any prescription or non-prescription medication from 2 weeks before and throughout the study, and were instructed to abstain from grapefruit, grapefruit juice, herbal dietary supplements, and caffeine-containing beverages including coffee and green tea 3 days before and throughout the study. Only subjects fulfilling above criteria were included.

\section{Genotyping of $A B C B 1$ polymorphism}

A blood sample $(2 \mathrm{ml})$ was obtained from each subject, and DNA was extracted from peripheral whole blood of each subject using an EZ-10 Spin Column Genomic DNA Minipreps Kit (for blood) (Bio Basic Inc.). The genotypes of 2677T/A, 3435T and CYP3A5 ${ }^{*} 3 /{ }^{*} 3$ were determined, respectively, with allele-specific polymerase chain reaction (AS$P(R)$, polymerase chain reaction-restriction fragment length polymorphism analysis (RFLP-PCR), and direct sequencing [31]. 
To verify the results obtained from gel electrophoresis analysis of AS-PCR or RFLP-PCR, samples of each genotype (homozygous wild-type, heterozygous, and homozygous polymorphism, a total of 15 samples) were sequenced. The confirmed genotypes allowed us to use the common nomenclature 2677T/A, and 3435T for such sites (GenBank accession numbers NC000007, NM000927).

\section{Pharmacokinetic study}

After overnight fasting for $10 \mathrm{~h}$, each subject received a single oral dose of $80 \mathrm{mg}$ verapamil with $240 \mathrm{ml}$ of water (verapamil (immediate-release tablet, $40 \mathrm{mg}$, Batch no. 061001, Central Pharmaceutical Co., Ltd of Tianjin, China)). Standardized meals were served $4 \mathrm{~h}$ and $10 \mathrm{~h}$ after dosing. Venous blood samples were collected at pre-dose $(0 \mathrm{~h})$ and $0.33,0.67,1,1.5,2,3,4,6,8,12$ and $24 \mathrm{~h}$ post-dosing. All blood samples were collected into lithium heparin-coated tubes and centrifuged immediately. Plasma samples were stored at $-20^{\circ} \mathrm{C}$ until use.

Plasma verapamil concentrations were analyzed using validated high-performance liquid chromatography (HPLC) with fluorescence detection as described previously with a slight modification. A linearity calibration curve in the range of $1-100 \mathrm{ng} \mathrm{ml}^{-1}$ was established for verapamil $\left(r^{2}=0.9973\right)$. Intra- and inter-day coefficients of variation $(\mathrm{CV})$ were $<15 \%$ and $<10 \%$, respectively.

The peak plasma concentration $\left(C_{\max }\right)$ and the time to reach $C_{\max }\left(t_{\max }\right)$ were estimated directly from the observed data. The plasma concentration-time curve for time $0-24 \mathrm{~h}$ $($ AUC (last)) was calculated using the linear trapezoidal rule. The AUC from time 0 to infinity $(A \cup C(0, \infty)$ was calculated as $\operatorname{AUC}(0, \infty)=\operatorname{AUC}($ last $)+C_{\mathrm{t}} / k_{\mathrm{e}}$, where $C_{\mathrm{t}}$ was the lastmeasured plasma concentration and $k_{\mathrm{e}}$ was determined using linear regression analysis of the logarithm-linear part of the plasma concentration-time curve. The half-life $\left(t_{1 / 2}\right)$ of verapamil was calculated as $t_{1 / 2}=\ln 2 / k_{\mathrm{e}}$. The apparent oral clearance $(\mathrm{CL} / F)$ of verapamil was calculated as $\mathrm{CL} / F=$ dose/AUC $C_{\text {inf. }}$

\section{Statistical analysis}

All data were expressed as mean $\pm \mathrm{SD}$. Normally distributed data were analyzed with one-way ANOVA (for multigroup comparison) or LSD or S-N-K-test (for two-group comparison). Non-normally distributed data were analyzed with Mann-Whitney U-test (for two-group comparison) or Kruskal-Wallis H-test (for multi-group comparison). Statistical analysis was carried out using the SPSS package (version 11.0; SPSS Inc., Chicago, IL, USA). A $P$ value $<0.05$ was considered to be statistically significant.

\section{Results}

All subjects had completed the study without clinically important adverse effects.

\section{Genotype-phenotype correlations}

Pharmacokinetic parameters of verapamil for different genotypic groups were summarized. As shown in Table 1, plasma concentrations in the $2677 \mathrm{GT} / 3435 \mathrm{CT}$ and 2677TT/ 3435TT groups were lower than those of the $2677 \mathrm{GG} /$ 3435CC group (Figure 1). A statistical difference $(P<0.01)$ was observed between all paired groups except for the 2677TT/3435TT and 2677GT/3435CT groups $(P>0.05)$. Average values of $\mathrm{AUC}$ (last) were significantly higher $(P<0.01)$ in the $2677 \mathrm{GG} / 3435 C \mathrm{C}$ group (303.1 \pm $83.7 \mathrm{ng} \mathrm{ml}^{-1} \mathrm{~h}$ ) as compared with the $2677 \mathrm{GT} / 3435 \mathrm{CT}$ (189.3 $\pm 73.1 \mathrm{ng} \mathrm{ml}^{-1} \mathrm{~h}$ ) and 2677TT/3435TT groups (159.5 $\pm 79.0 \mathrm{ng} \mathrm{ml}^{-1} \mathrm{~h}$ ). In addition, apparent oral clearance of verapamil was, respectively, $44 \%$ and $52 \%$ lower in the

Table 1

Pharmacokinetic profiles of verapamil in different genotypic groups following administration of a single dose of verapamil (80 mg)

\begin{tabular}{|c|c|c|c|c|c|c|}
\hline \multirow[b]{2}{*}{ Parameter } & \multicolumn{3}{|l|}{ Genotype group } & \multicolumn{3}{|c|}{ Multiple comparison } \\
\hline & (Group I, $n=6$ ) & (Group II, $n=12$ ) & (Group III, $n=6$ ) & II vs I & III vs I & III vs II \\
\hline $\begin{array}{l}C_{\max }\left(\mathrm{ng} \mathrm{ml}^{-1}\right) \\
(95 \% \mathrm{Cl})\end{array}$ & $\begin{array}{r}42.2 \pm 3.9 \\
(30.6,53.8)\end{array}$ & $\begin{array}{l}32.2 \pm 16.2 \\
(24.0,40.3)\end{array}$ & $\begin{array}{l}38.1 \pm 13.7 \\
(26.5,49.6)\end{array}$ & 0.156 & 0.607 & 0.396 \\
\hline $\begin{array}{l}t_{\max } \\
(95 \% \mathrm{Cl})\end{array}$ & $\begin{array}{l}3.00 \pm 1.79 \\
(2.00,3.98)\end{array}$ & $\begin{array}{l}2.29 \pm 0.92 \\
(1.60,2.99)\end{array}$ & $\begin{array}{l}1.75 \pm 0.76 \\
(0.77,2.73)\end{array}$ & 0.234 & 0.075 & 0.360 \\
\hline $\begin{array}{l}\text { Half-life (h) } \\
(95 \% \mathrm{Cl})\end{array}$ & $\begin{array}{l}7.33 \pm 2.18 \\
(5.91,8.76)\end{array}$ & $\begin{array}{l}6.23 \pm 1.55 \\
(5.23,7.24)\end{array}$ & $\begin{array}{l}6.48 \pm 1.35 \\
(5.06,7.91)\end{array}$ & 0.204 & 0.391 & 0.769 \\
\hline $\begin{array}{l}\text { AUC(last) }\left(\mathrm{ng} \mathrm{ml}^{-1} \mathrm{~h}\right) \\
(95 \% \mathrm{Cl})\end{array}$ & $\begin{array}{r}303.1 \pm 83.7 \\
(237.6,368.6)\end{array}$ & $\begin{array}{r}189.3 \pm 73.1 \\
(142.9,235.6)\end{array}$ & $\begin{array}{l}159.5 \pm 79.0 \\
(94.0,225.0)\end{array}$ & 0.008 & 0.004 & 0.449 \\
\hline $\begin{array}{l}\operatorname{AUC}(0, \infty)\left(\mathrm{ng} \mathrm{ml}^{-1} \mathrm{~h}\right) \\
(95 \% \mathrm{Cl})\end{array}$ & $\begin{array}{r}322.4 \pm 93.7 \\
(255.3,389.5)\end{array}$ & $\begin{array}{r}203.0 \pm 73.8 \\
(155.5,250.5)\end{array}$ & $\begin{array}{r}172.1 \pm 74.1 \\
(105.0,239.0)\end{array}$ & 0.007 & 0.003 & 0.443 \\
\hline $\begin{array}{l}\mathrm{CL} / F\left(\mathrm{I} \mathrm{h}^{-1}\right) \\
(95 \% \mathrm{Cl})\end{array}$ & $\begin{array}{r}265.4 \pm 72.8 \\
(125.6,405.1)\end{array}$ & $\begin{array}{l}452.2 \pm 188.6 \\
(353.4,551.0)\end{array}$ & $\begin{array}{c}523.0 \pm 173.7 \\
(383.3,662.7)\end{array}$ & 0.034 & 0.013 & 0.399 \\
\hline
\end{tabular}

Data are shown as mean $\pm \mathrm{SD}$. $t_{\max }$ is given as median (range). $C_{\max }$, Peak plasma concentration; $t_{\max }$, time to $C_{\max } ; A U C$ (last), area under the concentration-time curve from 0 to $24 \mathrm{~h}$; $\mathrm{AUC}(0, \infty)$, area under the concentration-time curve from 0 to infinity; $C L / F$, oral clearance. 


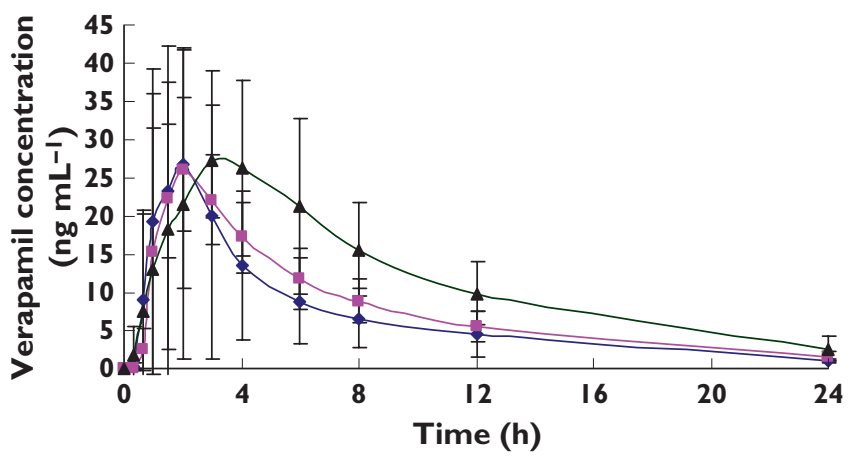

\section{Figure 1}

Plasma concentration-time curve following oral administration of $80 \mathrm{mg}$ verapamil. Values are given as mean \pm SD. $2677 \mathrm{GG} / 3435 C C$ ( $\mathbf{\Delta}$ ); 2677GT/3435CT(ロ); 2677TT/3435TT(•)

$2677 G G / 3435 C C$ group than in the $2677 G T / 3435 C T$ and 2677TT/3435TT groups $(P<0.01)$. The elimination half-life $\left(t_{1 / 2}\right)$ of verapamil also appeared to be greater in the $2677 \mathrm{GG} / 3435 \mathrm{CC}$ group ( $7.33 \mathrm{~h}$ vs $6.23 \mathrm{~h}$ and $6.48 \mathrm{~h}$ ). This difference, however, was not statistically significant $(P>$ $0.05)$, possibly due to inter-individual variability as well as the small number of recruited subjects. No significant difference was found with other pharmacokinetic parameters among the three groups.

As shown by the result, all subjects had a CYP $3 A{ }^{*} 3 /{ }^{*} 3$ genotype. This frequency $(24 / 24,100 \%)$ was higher than that reported (72\%) partly because our subjects were nonrandomly recruited.

\section{Discussion}

Inter-individual variability in drug efficacy and toxicity, which may result in unpredictable drug responses, is common in clinical settings. This may be due to sequence variants in genes encoding drug metabolism enzymes, drug transporters and/or drug targets [32]. At least 105 variants have been identified with the $A B C B 1$ gene, together with significant differences in their frequencies among different ethnic groups. Given the known interpopulation differences in drug response for verapamil, it may be important to consider variability among ethnic groups by characterizing variability in genotypes, linkage disequilibrium and recombination within and between ethnic populations. 1236T has been regarded as one of the most frequent SNPs contributing to the $A B C B 1$-related phenotypes [33]. During the past few years, researchers have studied the effect of $A B C B 1$ haplotypes on the pharmacokinetics of digoxin $[16,34]$, cyclosporin $[24,35]$, tacrolimus [36] and amlodipine [37]. Notably, in such studies, all haplotype construction had been limited to two SNPs, i.e. $3435 \mathrm{~T}$ and $2677 \mathrm{~T} / \mathrm{A}$. Therefore, we decided to recruit subjects simultaneously featuring wild, heterozygous or mutant types for such polymorphisms in present study.
Pharmacokinetics parameters of verapamil $\left(C_{\max } 36.14\right.$ $\pm 13.73 \mathrm{ng} \mathrm{ml}^{-1}$, AUC $210.3 \pm 92.7 \mathrm{ng} \mathrm{ml}^{-1} \mathrm{~h}, t_{\max } 2.3 \pm$ $1.2 \mathrm{~h}$, and $t_{1 / 2} 6.6 \pm 1.7 \mathrm{~h}$ ) from our results were consistent with those reported by McAllister et al. [38], but with lower $C_{\max }$ and AUC when compared with those reported by Horne et al. and Hla et al. [39,40]. This may be due in part to factors such as ethnicity, sample size and the large interindividual variability of the drug.

As suggested from our results, individuals carrying two copies of mutant $A B C B 1$ alleles (2677TT/3435TT) have an increased apparent oral clearance of verapamil when compared with heterozygotes (2677GT/3435CT) or carriers of wild-type alleles (2677GG/3435CC). Meanwhile, AUC values in such subjects were $47.3 \%$ and $37.5 \%$ lower than in those with $2677 G T / 3435 C T$ or $2677 G G / 3435 C C$ genotypes. This seems to suggest that $2677 / 3435$ genotypes are likely to be a major factor responsible for the inter-individual differences in pharmacokinetics of verapamil.

In accordance with our results, higher amlodipine plasma concentrations, AUC and lower clearance have also been associated with the $2677 \mathrm{GG} / 3435 \mathrm{CC}$ genotype in healthy Korean volunteers [38]. In another report, it was shown that patients with the $2677 \mathrm{G} / 3435 \mathrm{C}$ genotype had significantly better response to chemotherapy when compared with those with other genotypes [41]. By contrast, in a recent study, Pan et al. showed that 2677TT/3435TT subjects had slightly, but not significantly higher $C_{\max }$ and AUC and lower $t_{\max }$ for verapamil than did $2677 \mathrm{GG} / 3435 \mathrm{CC}$ subjects [42]. The absorption/first-pass effect of oral immediate-release tablets of verapamil is characterized by a saturable process that results in nonlinear pharmacokinetics and may show considerable inter- and intra-subject variability [43]. Therefore, the discrepancy between Pan et al. and our results may be attributed to saturable transporter kinetics with higher verapamil doses. Similar results have been shown with digoxin [15, 16, 44].

Clinically available verapamil is a racemic mixture of equal amounts of the R- and S-verapamil. In vitro and in vivo studies, however, have shown that the R-verapamil is 10 -fold less potent than the S-verapamil as a calcium antagonist. Due to stereoselective first-pass metabolism, the plasma R-verapamil concentration was five times greater than that of the S-verapamil following oral administration. On the other hand, Hollt et al. found that both enantiomers had almost equivalent P-gp-inhibitory activities [10].In this study, the calculated $E C_{50}$ of the R-verapamil appeared to be less than that of S-verapamil, i.e. $2.6 \mu \mathrm{M}$ vs $2.9 \mu \mathrm{M}$, but this was not statistically significant. Enantioselective interactions with P-gp were also observed in a study that had determined the $I C_{50}$ values associated with the P-gp binding affinities of the R- and S-verapamil [45]. These seemed in keeping with earlier findings by Gruber et al. [46], Plumb et al. [47] and Keilhauer et al. [48]. Based on the above findings, we may expect that the effects of the R- and S-verapamil on P-gp are similar to verapamil enantiomers among different genotypic groups. 
Polymorphisms of $A B C B 1$ gene on the pharmacokinetics of verapamil $B] C P$

Additional studies involving a larger sample size and stratification based on haplotypes may still be necessary for the understanding of the influence of $A B C B 1$ gene variants on the disposition, therapeutic response and toxicity of verapamil. To reduce the risk of spurious association between $A B C B 1$ genotypes and in vivo phenotypes, demographic data of the selected subjects as well as sample size and environmental factors should also be considered carefully. Notably, factors other than the investigated genotypes may also contribute to the observed inter-individual variations. Although most nucleotide variants, including the studied ones, are mapped within the coding regions of $A B C B 1$, variations in the promoter region of the gene have also been suggested to be important for inter-individual differences in terms of P-gp expression, luciferase activity, and placental and hepatic mRNA levels [49].

In conclusion, we have provided the first evidence that $A B C B 1$ gene polymorphism may have a considerable impact on the pharmacokinetics of verapamil among healthy Chinese Han ethnic subjects. Genotyping the gene may provide useful information for individualizing the treatment by optimizing drug dosage.

\section{Competing interests}

None declared.

We thank all our subjects for their participation in this study. We also thank our technicians for their excellent assistance with chemical analysis.

\section{REFERENCES}

1 Halperin AK, Cubeddu LX. The role of calcium channel blockers in the treatment of hypertension. Am Heart J 1986; 111:363-82.

2 McAllister RG Jr, Hamann SR, Blouin RA. Pharmacokinetics of calcium-entry blockers. Am J Cardiol 1985; 55: 30B-40B.

3 Dadashzadeh S, Javadian B, Sadeghian S. The effect of gender on the pharmacokinetics of verapamil and norverapamil in humans. Biopharm Drug Dispos 2006; 27 : 329-34.

4 Choi DH, Shin WG, Choi JS. Drug interaction between oral atorvastatin and verapamil in healthy subjects: effects of atorvastatin on the pharmacokinetics of verapamil and norverapamil. Eur J Clin Pharmacol 2008; 64: 445-9.

5 Choi JS, Han HK. The effect of quercetin on the pharmacokinetics of verapamil and its major metabolite, norverapamil in rabbits. J Pharm Pharmacol 2004; 56: 1537-42.

6 Ho PC, Ghose K, Saville D, Wanwimolruk S. Effect of grapefruit juice on pharmacokinetics and pharmacodynamics of verapamil enantiomers in healthy volunteers. Eur J Clin Pharmacol 2000; 56: 693-8.

7 Kerb R, Hoffmeyer S, Brinkmann U. ABC drug transporters: hereditary polymorphisms and pharmacological impact in MDR1, MRP1 and MRP2. Pharmacogenomics 2001; 2: 51-64.

8 Sakaeda T, Nakamura T, Okumura K. MDR1 genotype-related pharmacokinetics and pharmacodynamics. Biol Pharm Bull 2002; 25: 1391-400.

9 Leonard GD, Fojo T, Bates SE. The role of ABC transporters in clinical practice. Oncologist 2003; 8: 411-24.

10 Hollt V, Kouba M, Dietel M, Vogt G. Stereoisomers of calcium antagonists which differ markedly in their potencies as calcium blockers are equally effective in modulating drug transport by p-glycoprotein. Biochemistry and. Pharmacology 1992; 40: 2601-8.

11 Chiou WL, Chung SM, Wu TC, Ma C. A comprehensive account on the role of efflux transporters in the gastrointestinal absorption of 13 commonly used substrate drugs in humans. Int J Clin Pharmacol Ther 2001; 39: 93-101.

12 Yumoto R, Murakami T, Takano M. Differential effect of acute hepatic failure on in vivo and in vitro P-glycoprotein functions in the intestine. Pharm Res 2003; 20:765-71.

13 Bosch TM, Meijerman I, Beijnen JH, Schellens JH. Genetic polymorphisms of drug-metabolizing enzymes and drug transporters in the chemotherapeutic treatment of cancer. Clin Pharmacokinet 2006; 45: 253-85.

14 Becquemont L, Verstuyft C, Kerb R, Brinkmann U, Lebot M, Jaillon P, Funck-Brentano C. Effect of grapefruit juice on digoxin pharmacokinetics in humans. Clin Pharmacol Ther 2001; 70: 311-6.

15 Gerloff T, Schaefer M, Johne A, Oselin K, Meisel C, Cascorbi I, Roots I. MDR1 genotypes do not influence the absorption of a single oral dose of $1 \mathrm{mg}$ digoxin in healthy white males. Br J Clin Pharmacol 2002; 54: 610-6.

16 Johne A, Kopke K, Gerloff T, Mai I, Rietbrock S, Meisel C, Hoffmeyer S, Kerb R, Fromm MF, Brinkmann U,

Eichelbaum M, Brockmoller J, Cascorbi I, Roots I. Modulation of steady-state kinetics of digoxin by haplotypes of the P-glycoprotein MDR1 gene. Clin Pharmacol Ther 2002; 72: 584-94.

17 Kurata Y, leiri I, Kimura M, Morita T, Irie S, Urae A, Ohdo S, Ohtani H, Sawada Y, Hiquchi S, Otsubo K. Role of human MDR1 gene polymorphism in bioavailability and interaction of digoxin, a substrate of P-glycoprotein. Clin Pharmacol Ther 2002; 72: 209-19.

18 Verstuyft C, Schwab M, Schaeffeler E, Kerb R, Brinkmann U, Jaillon P, Funck-Brentano C, Becquemont L. Digoxin pharmacokinetics and MDR1 genetic polymorphisms. Eur J Clin Pharmacol 2003; 58: 809-12.

19 Verstuyft C, Strabach S, El-Morabet H, Kerb R, Brinkmann U, Dubert L, Jaillon P, Funck-Brentano C, Truqnan G, Becquemont L. Dipyridamole enhances digoxin bioavailability via P-glycoprotein inhibition. Clin Pharmacol Ther 2003; 73: 51-60.

20 Keller F, Rietbrock N. Bioavailability of digoxin: some pitfalls and problems. Int J Clin Pharmacol Biopharm 1977; 15: 549-56. 
21 Sakaeda T, Nakamura T, Horinouchi M, Kakumoto M, Ohmoto N, Sakai T, Morita Y, Tamura T, Aoyama N, Hirai M, Kasuqa M, Okumura K. MDR1 genotype-related pharmacokinetics of digoxin after single oral administration in healthy Japanese subjects. Pharm Res 2001; 18: 1400-4.

22 Kim RB, Leake BF, Choo EF, Dresser GK, Kubba SV, Schwarz UI, Taylor A, Xie HG, McKinsey J, Zhou S, Lan LB, Schuetz JD, Schuetz EG, Wilkinson GR. Identification of functionally variant MDR1 alleles among European Americans and African Americans. Clin Pharmacol Ther 2001; 70: 189-99.

23 Horinouchi M, Sakaeda T, Nakamura T, Morita Y, Tamura T, Aoyama N, Kasuga M, Okumura K. Significant genetic linkage of MDR1 polymorphisms at positions 3435 and 2677: functional relevance to pharmacokinetics of digoxin. Pharm Res 2002; 19: 1581-5.

24 Chowbay B, Cumaraswamy S, Cheung YB, Zhou Q, Lee EJ. Genetic polymorphisms in MDR1 and CYP3A4 genes in Asians and the influence of MDR1 haplotypes on cyclosporin disposition in heart transplant recipients. Pharmacogenetics 2003; 13: 89-95.

25 Tan EK, Chan DK, Ng PW, Woo J, Teo YY, Tang K, Wong LP, Chong SS, Tan C, Shen H, Zhao Y, Lee CG. Effect of MDR1 haplotype on risk of Parkinson disease. Arch Neurol 2005; 62: 460-4.

26 Sata F, Sapone A, Elizondo G, Stocker P, Miller VP, Zheng W, Raunio H, Crespi CL, Gonzalez FJ. CYP3A4 allelic variants with amino acid substitutions in exons 7 and 12: evidence for an allelic variant with altered catalytic activity. Clin Pharmacol Ther 2000; 67: 48-56.

27 Ball SE, Scatina J, Kao J, Ferron GM, Fruncillo R, Mayer P, Weinrvb I, Guida M, Hopkins PJ, Warner N, Hall J. Population distribution and effects on drug metabolism of a genetic variant in the 5 'promoter region of CYP3A4. Clin Pharmacol Ther 1999; 66: 288-94.

28 Jin Y, Wang YH, Miao J, Li L, Kovacs RJ, Marunde R, Hamman MA, Phillips S, Hilligoss J, Hall SD. Cytochrome P450 3A5 genotype is associated with verapamil response in healthy subjects. Clin Pharmacol Ther 2007; 82: 579-85.

29 Langaee TY, Gong Y, Yarandi HN, Katz DA, CooperDeHoff RM, Pepine CJ, Johnson JA. Association of CYP3A5 polymorphisms with hypertension and antihypertensive response to verapamil. Clin Pharmacol Ther 2007; 81: 386-91.

30 Kuehl P, Zhang J, Lin Y, Lamba J, Assem M, Schuetz J, Watkins PB, Daly A, Wrighton SA, Hall SD, Maurel P, Relling M, Brimer C, Yasuda K, Venkataramanan R, Strom S, Thummel K, Boquski MS, Schuetz E. Sequence diversity in CYP3A promoters and characterization of the genetic basis of polymorphic CYP3A5 expression. Nature Genet 2001; 27: 383-91.

31 Kurzawski M, Pawlik A, Gornik W, Drozdzik M. Frequency of common MDR1 gene variants in a Polish population. Pharmacol Rep 2006; 58: 35-40.

32 Evans WE, Relling MV. Pharmacogenomics: translating functional genomics into rational therapeutics. Science 1999; 286: 487-91.
33 Anglicheau D, Thervet E, Etienne I, Hurault de Ligny B, Le Meur Y, Touchard G, Büchler M, Laurent-Puig P, Tregouet D, Beaune $P$, Daly A, Legendre C, Marquet $P$. CYP3A5 and MDR1 genetic polymorphisms and cyclosporine pharmacokinetics after renal transplantation. Clin Pharmacol Ther 2004; 75: 422-33.

34 Kurzawski M, Bartnicka L, Florczak M, Górnik W, Drozdzik M. Impact of $A B C B 1$ (MDR1) gene polymorphism and Pglycoprotein inhibitors on digoxin serum concentration in congestive heart failure patients. Pharmacol Rep 2007; 59: 107-11.

35 Mai I, Störmer E, Goldammer M, Johne A, Krüger H, Budde K, Roots I. MDR1 haplotypes do not affect the steady-state pharmacokinetics of cyclosporine in renal transplant patients. J Clin Pharmacol 2003; 43: 1101-7.

36 Mai I, Perloff ES, Bauer S, Goldammer M, Johne A, Filler G, Budde K, Roots I. MDR1 haplotypes derived from exons 21 and 26 do not affect the steady-state pharmacokinetics of tacrolimus in renal transplant patients. Br J Clin Pharmacol 2004; 58: 548-53.

37 Kim KA, Park PW, Park JY. Effect of ABCB1 (MDR1) haplotypes derived from G2677T/C3435T on the pharmacokinetics of amlodipine in healthy subjects. Br J Clin Pharmacol 2007; 63: 53-8.

38 McAllister RG Jr, Kirsten EB. The pharmacology of verapamil. IV. Kinetic and dynamic effects after single intravenous and oral doses. Clin Pharmacol Ther 1982; 31:418-26.

39 Horne C, Stenzhorn G, Blume H, Knauf H, Mutschler E. Bioavailability study of two different verapamil formulations. Arch Pharm (Weinheim) 1992; 325: 531-6.

40 Hla KK, Latham AN, Henry JA. Influence of time of administration on verapamil pharmacokinetics. Clin Pharmacol Ther 1992; 51:366-70.

41 Sohn JW, Lee SY, Lee SJ, Kim EJ, Cha SI, Kim CH, Lee JT, Jung TH, Park JY. MDR1 polymorphisms predict the response to etoposide-cisplatin combination chemotherapy in small cell lung cancer. Jpn J Clin Oncol 2006; 36: 137-41.

42 Pan W, Ryu JY, Shon JH, Song IS, Liu KH, Sunwoo YE, Kang W, Shin JG. Dietary salt dose not influence the disposition of verapamil enantiomers in relation to efflux transporter ABCB1 genetic polymorphism in healthy Korean subjects. Xenobiotica 2008; 38: 422-34.

43 Harder S, Thurmann P, Siewert M, Blume H, Huber TH, Rietbrock N. Pharmacodynamic profile of verapamil in relation to absolute bioavailability: investigations with a conventional and controlled release formulation. J Cardiovasc Pharmacol 1991; 17: 207-12.

44 Hoffmeyer S, Burk O, von Richter O, Arnold HP, Brockmoller J, Johne A, Cascorbi I, Gerloff T, Roots I, Eichelbaum M, Brinkmann U. Functional polymorphisms of the human multidrug-resistance gene:multiple sequence variations and correlation of one allele with P-glycoprotein expression and activity in vivo. Proc Natl Acad Sci U S A 2000; 97: 3473-8.

45 Neuhoff S, Langguth P, Dressler C, Andersson TB, Regardh CG, Spahn-Langguth H. Affinities at the verapamil 
Polymorphisms of $A B C B 1$ gene on the pharmacokinetics of verapamil $B] C P$

binding site of MDR1-encoded P-glycoprotein: Drugs and analogs, stereoisomers and metabolites. Int J Clin Pharmacol Ther 2000; 38: 168-79.

46 Gruber A, Peterson C, Reizenstein P. D-verapamil and L-verapamil are equally effective in increasing vincristine accumulation in leukemic cells in vitro. Int J Cancer 1988; 41: 224-6.

47 Plumb JA, Milroy R, Kaye SB. The activity of verapamil as a resistance modifier in vitro in drug resistant human tumor cell lines is not stereospecific. Biochem Pharmacol 1990; 39: 787-92.
48 Keilhauer C, Emling F, Raschak M, Gries J, Schlick E. The use of R-verapamil (R-VPM) is superior to racemic VPM in breaking multidrug resistance (MDR) of malignant cells. Proc Am Assoc Cancer Res 1989; 30:503 (Abstract).

49 Takane H, Kobayashi D, Hirota T, Kiqawa J, Terakawa N, Otsubo K, leiri I. Haplotype-oriented genetic analysis and functional assessment of promoter variants in the MDR1 $(A B C B 1)$ gene. J Pharmacol Exp Ther 2004; 311: 1179-87. 